\title{
Imagining Cities, Living the Other: Between the Gay Urban Idyll and Rural Lesbian Lives
}

\author{
K. Browne*
}

School of the Environment, Cockcroft Building, Lewes Road, Brighton, BN2 4GJ, UK

\begin{abstract}
By focusing on often neglected lesbian geographies, this paper deconstructs the urban/rural divide which has pervaded discussions of (sexual) geographies. In particular, the paper addresses the intersections between imaginings of urban idylls (what could be termed the urban gay) and how these places 'beyond' can, in part, (in)form everyday lives in small towns (what could be termed the lesbian rural). In doing this, the paper furthers lesbian geographies by examining how fantasises and imaginings of cities become important to 22 lesbians women who live in a small town in the South West of England. The problematic assumptions of visible sexual expressions and 'gay' territories as central defining features of lives outside heterosexuality are contested. The paper examines the messy interstices, movements and interactions between towns and cities in the UK, through lesbian negotiations and understandings of everyday life.
\end{abstract}

Keywords: Urban, rural, sexuality, qualitative, power, lesbian.

\section{INTRODUCTION}

Geographies of sexualities have conceptualised cities, as Weston notes, as an 'escape from the isolation of the countryside and the surveillance of small-town life in contrast to the freedom and anonymity of the urban landscape' [1] p. 274) [1$3]$. In this way 'cities' have often been constructed as urban utopias which beckon those who wish to enact 'deviant' sexualities $[1,4]$. By contrast, the safety of gay ghettos within cities has been brought into question [5] and the rural has also been advanced as a site of sexual liberation [6-8]. However urbanities do not exist in isolation from ruralities and as Bell [9] contends the city and the country exist 'hand in hand ... each making and remaking the other' (p. 99). The relational constitution of cities/towns/villages/ruralities unsettles the urban/rural divide, revealing that the urban and rural, while useful in discussions within (gay/lesbian/non-heterosexual) geographies has particular limitations. Some of these have been highlighted in terms of movement, embodiments and unfixities [2, 4], yet how the urban/rural binary is lived as fixed rather than moveable and fluid has yet to be examined. By deconstructing the urban/rural binary in relation to sexual, practices identities and particularly imaginings this paper aims to augment lesbian geographies beyond urban spaces.

Focusing on those women who do not people cities on a daily basis but live in smaller towns- the paper departs from the urban studies focus on those who roam, read and write (usually heterosexual, but at times gay, men), to those who also live in, practice and perceive these places. Jarvis et al. [10] reveal the complexities of everyday city living through an examination of the mundane movements and practices of heterosexual households. Challenging the heterosexist and gendered considerations of urban/rural binary by exploring

*Address correspondence to this author at the School of the Environment, Cockcroft Building, Lewes Road, Brighton, BN2 4GJ, UK; Tel: +44 1273 642377; E-mail: K.a.browne@brighton.ac.uk lesbian ${ }^{1}$ geographies, it can be seen that different epistemologies may be necessary to render visible that which is often made invisible [14-16]. With the queer turn and other discussions of GLBT/LGBT ${ }^{2}$ as well as other sexual collectivities, lesbian $^{3}$ voices can be omitted and forgotten [15, 19-21]. In the queer turn, the drive to deconstruct identities and the quest to find anti-normativities often marginal positions, has yielded productive insights [18, 22-26]. However, this has also meant that the 'centres' of LGBT collectives, namely lesbians/gay men, can be omitted as legitimate subjects of investigation. Such a move is problematic and in this context, it closes down useful ways of reconceptualising urban/rural and lesbian spatial imaginings. Conversely, gay male voices, with the rise of geographies of masculinities [27], are often (controversially) posed as a making masculinities 'complex' and not necessarily hegemonic. Therefore reusing and feminising Bell's rural homosexual and homosexual rural, lesbian conceptualisations of places (including perceptions, fantasies and imaginings) are examined. These cannot be proved, ordered or fixed and yet are necessary to (re)conceptualise lesbian (as well as other sexual identities) uses and engagements with everyday spaces.

Following an outline of the methods used, the paper will discuss geographies of sexualities, urban/rural differentiations

\footnotetext{
${ }^{1}$ This paper will not attempt to define or essentialise 'lesbian geographies', rather it will use this term to explore the gendered and sexualised understandings of everyday lives and the urban/rural constructions. This draws on Butler's [11] contention that she will use lesbian, as long as it is permanently unclear what this means. Moreover, whilst recognising the intersections of sexuality and class [12], race/ethnicity [13] and other social differences, this paper does not address these.

${ }^{2}$ GLBT- Gay Lesbian, Bisexual and Trans- is commonly used in North America, whereas LGBT- Lesbian, Gay, bisexual and Trans-, which puts lesbian at the forefront is more often used in the United Kingdom.

${ }^{3}$ The term lesbian is used to include people who live as women but not within heterosexual relations. Individuals may/may not identify with labels and categories such as lesbian or gay. It is should be noted that this paper does not account for asexual women or other forms of 'queer' identities. Moreover, the use of the category 'lesbian' is one that recognises the focus on men in the geographies of sexualities literature $[17,18]$.
} 
and their continued symbolic importance. Turning to the research narratives, lesbian/non-heterosexual women's perceptions of cities and how participants act in small towns in relation to these geographical imaginings are explored. In further examining these 'fantasies' it is argued that the blurring of boundaries between urban and rural are necessary to conceptualise lesbian lives through the reconstitution of urban cultural 'fantasies'. The paper finally refutes the homogenisation of urban utopias and restrictive ruralities. In this way the paper will investigate the interplay between lesbian/nonheterosexual women's imaginings of cities and accounts of their everyday geographies in towns to look at how the cities 'beyond' reconstitute everyday lives in towns.

\section{METHODS}

The paper draws on my doctoral research which sought to consider the sites and processes of material power that act to (re)produce the everyday lives of non-heterosexual women. The research itself consisted of six focus groups, three coupled interviews, 23 individual interviews. Participants were recruited using snowball sampling which began with my own personal networks [28]. The 28 women were all white, able bodied and aged between 18 and 45, with the majority of the sample consisting of women aged between 18 and 30. A deconstruction of their whiteness and age is beyond the scope of this paper, suffice to note that these are not unproblematic categories and to point to the racial reconstitution of these women's experiences. They were living in two small towns and two cities in the South-West of England. Fieldtown has one gay club and two gay pubs. Hilltown has no gay pubs or clubs, but one pub was described as 'gay friendly'. Both blue city and green city had identifiable gay areas with pubs and clubs (see Table 1 below). The majority of women (22 out of 28) lived in Fieldtown (population 110,000) because I was known in this town and thus had access to lesbian/nonheterosexual women who would have been reluctant to talk to strangers about issues of sexuality. These women are the focus of this paper.

Whilst geographically limited and necessarily subjective, my social and personal networks were effective in recruiting women who are often 'hidden' in studies of sexualities [28, 29]. Beyond the scant details here, towns and cities are not identified or described in order to protect participants' identities. This is important given the small networks in towns. Providing descriptors of towns could lead to their identification and consequently reveal participants identities. Participants' were assured that towns would not be named in publications and this promise will be upheld here.

Once interviews, focus groups, and coupled interviews had been undertaken, the information was coded and categorised. NUD*IST was used as an indexing tool with themes and sub themes being formed using the data collected and then used to code the data. Large themes were broken into sub themes with these also being broken down further where appropriate. 82 themes and sub themes were created using the data these were placed under four major headings. One aspect of the 28

\footnotetext{
${ }^{4}$ A full discussion and justification of this sampling technique and its implications for research accounts is beyond the scope of this paper and are described elsewhere $[28,29]$. Suffice to note that the majority of women in this study were not 'out' about their sexualities and would therefore be hidden to researchers who recruit using organised lesbian groups.
}

women's narratives that emerged in this process was their contrasting images of small towns and cities and their related discussion of what they do (not) and would (not) do in these places. As these narratives were drawn together it became clear that these both drew on, and contested, utopian stereotypes of cities and restrictive ruralities. Using both direct quotes and summaries of these narratives, the paper offers insights into how the 22 women in this research who live in small towns negotiate their lives at the intersection between the symbolic and everyday materialities.

\section{Table 1. Summary of where Participants Lived}

\begin{tabular}{|l|c|}
\hline Where Participants Live & Number of Women \\
\hline \hline Fieldtown (1 gay club, 2 gay pubs) & 22 \\
\hline Hilltown (no specifically gay venues) & 3 \\
\hline Blue city (three gay clubs, seven gay pubs) & 2 \\
\hline Green city (three gay clubs and five gay pubs) & 1 \\
\hline \multicolumn{1}{|c|}{ Total } & $\mathbf{2 8}$ \\
\hline
\end{tabular}

\section{URBAN UTOPIAS, RURAL REPRESSIONS}

It is usual to subsume geographies of sexualities to 'broader' discussions of urban/rural. Beginning with geographies of sexualities disrupts the assertion that often heterosexualised discussions of urban/rural should take precedence over an examination of geographies of sexualities. The history and development of geographies of sexualities is well documented [30-33]. Here it is important to note that geographies of sexualities began with the mapping of gay ghettos as sites of political power, freedom and sexual expression, and this territorial emphasis continues to this day (see for example [34-38]). It has been argued that cities are heterosexualised differently dispelling the myth of a uniform 'urban' sexuality [39-42].

The dominance of representations of urban sexualities as universal and a necessary condition of sexual expressions has been contested $[6,7]$. Rural practices can in diverse ways be liberatory $[6,43]$. Investigations of ruralities have moved sexual practices away from categories of identities that rely on 'urban' manifestations of gay sexualities, such as gay ghettos, or even the necessity of defining within the category 'gay' or 'homosexual' [44, 45] and with the advent of 'queer' questioned the boundaries, privileges and normativities of such categories [18, 30, 46]. The re-claiming of a rural idyll within what is assumed to be oppressive countryside has been the task for some authors [2, 6, 43, 47]. Yet as Spurlin notes the rural is diverse and it is important not to essentialise particular places [48]. Moreover, Knopp and Brown [3] argue that the simple diffusion model that sees innovations as coming from urbanities and diffusing to ruralities is problematic. They go on to reveal complex spatialities challenging the view of big cities as 'urban utopias' and explore the multiple spatial scales that are negotiated in the creation of sexual subjectivities [2].

Contesting geographies of sexualities which focus on visible sexual expressions in 'gay' territories and deconstruction of rural idylls $[6,43,49]$, and recognising the extensive problematisation of the concepts of urban and rural [2, 42, 50, 51], I wish to concur with a classic piece from Halfacree [52]. He 
contends that despite the deconstruction of the 'rural' (and I would add 'lesbian'), this concept still retains importance within everyday discourses and ideological constructs. Similar to his assertions regarding the everyday use of rural concepts, cities can also hold an important conceptual and imagined place in daily life despite being theorised as fluid, (re)produced, and as an articulation of socio-spatial relations [53]. In other words, the rural and the urban as concepts continue to have particular salience despite the deconstruction of the categories and binaries that are implied by postmodern critical thought.

\section{GENDERING GEOGRAPHIES OF SEXUALITIES}

Although slowly increasing, within the (re)writings of geographies of sexualities and queer geographies, lesbians/nonheterosexual women's everyday lives continue to be marked by an 'absence of presence' $[15,16,54,55]$. Approaches to lesbian/non-heterosexual women within geographies of sexualities can, in part be summarised by Quilley [56] who states '[b]y gay community I refer mainly to men' (p. 49). This can be the case when documenting 'homosexual' histories of cities [57] perhaps because, as certain authors have argued, women and lesbians tend not to concentrate in a given territory, and because of this, lesbians are less likely to achieve local political power [58, 59]. Moreover, the absence of visible 'lesbian' areas has been attributed to gender and resulting lower incomes [58, 60]. Podmore [54] argues both urban geographies and urban geographies of sexualities have excluded 'lesbian' geographies in their desire to map and theorise visible 'gay' territories.

In moving beyond the focus on commodification and gay territories as signifiers of 'mappable' identities, lesbian geographies may not centralise facilities and sexual opportunities as markers of existence $[16,45]$, although recent research has foregrounded female appropriation of bathhouses [55, 61, 62]. The territorial visibilities that these facilities, and sexual opportunities, afford gay men may not be available to (and may not be sought by) women [63]. However as lesbian geographers have suggested this is not because non-heterosexual women do not use facilities or appropriate space in desiring ways. Rather, it is that the geographical focus of study and how geographers have examined sexualities can invisiblise lesbians', practices, politics, spaces, identities and lives [54, 63-65]. Lesbian geographies have examined unmapped (unmappable?) aspects of non-heterosexual women's lives contending that social networks and uses of space can challenge normative geographies [63, 64, 66, 67] as well as focusing on women's appropriation of gay, queer and heterosexual spaces $[54,68]$.

\section{BEYOND THE URBAN/RURAL?: UNDERSTANDING THE HOMOSEXUAL URBAN}

How towns and cities are constructed relationally has been examined in geographies of sexualities in terms of migration $[1,2]$, diffusion [3] and festivals [69]. Focusing on migration, authors such as Gorman-Murray, have questioned the urban/rural binary [2, 4], arguing for a hybrid understanding [69]. A hybrid model, offers one way of considering interconnections. It is important to explore the relations between diverse places, as Massey's [53] contends:
... the particularity of any place is... constructed not by placing boundaries around it and defining its identity through counter-position to the other which lies beyond, but precisely (in part) through the specificity of the mix of links and interconnections to that 'beyond' (p. 5).

The 'links' and interconnections Massey focuses on relate to globalisation. Here I wish to draw on the contention that imaginings and realities 'co-exist and interact' (p. 102) [7, 70] in the constitution of urban/rural places. Thus, 'links' and interconnections 'beyond' where people live interact with the materialities of everyday lives and perceptions of the places that they live in.

Since the 1990's social geographies engagements with the rural idyll have pointed to its diverse heterosexual (as well as racialised and classed) constructions [43, 71-74]. Bell [75] in bringing together rural and homosexual, argues that what he terms 'the homosexual rural' (the imagined) and 'the rural homosexual' (life experiences) are 'densely and complexly woven together' (p. 191). Contending that lives are lived between the material and symbolic, Bell opens up fruitful lines of enquiry that can build on Massey's [53] conception of places as in part being made by what is 'beyond'. Specifically, his contention that 'the homosexual urban ... exists as an equally mythological site to its rural counterpart, a place made in the imagination and unmatched in reality' ( $p .187$ ) points to the connections between places themselves and those 'beyond'. The homosexual urban is then 'an idyllic place conjured in the 'homosexual imagination' and represented across gay cultural forms' ([75] p. 191), this informs, but differs from, urban homosexual lives. This conceptualisation extends writings about 'urban imaginings' which vary, from the flaneur's street level experiences of the city, to the academics articulation of the international flows and webs of cities $[50,66$, 76-79].

Phillips [73] points out, towns are not quite urban, yet not entirely rural and therefore occupy a middle ground between the urban and the rural (see Knopp and Brown's [3, 80] discussion of different size cities in North America and the relationship with sexual geographies). Perceptions of place may also solidify borders between, and dichotomise, towns and cities attributing them (and lives associated with them) distinct characteristics. In investigating how perceptions and lives interact and (re)constitute each other it is possible to move between the divisions of urban/rural, town/city augmenting the complexities of lesbian geographies that can defy fixed forms of mapping $[15,16,54,55,61,81]$. Here, I will, tentatively, use (without presuming homogeneity) the terms 'towns' and 'cities' as participants have to examine how rural lesbian lives are interconnected with the mythical lesbian urban.

\section{READING CITIES, (RE)WRITING TOWNS}

The women who participated in this study labelled where they lived as either towns or cities and it is their classifications (including terms such as 'big' and 'small'), rather than official definitions, that are used here. Their discussions show how the boundaries between 'rural' and 'urban' (as well as big/small) can become blurred and that these terms are slippery with no straightforward meaning: 
Angela: I mean (name of 'city') there was absolutely nothing really.

Jenny: (Name of 'city') is a city.

Angela: It's only called a city cos it's got a cathedral (Jenny laughs) ... There's not a specific gay night club and I think there's only one or two gay pubs.

(Jenny, white $18-20^{5}$ and Angela, white 20-25, focus group, Fieldtown)

Angela argues that the 'city' she is from lacks amenities which cater specifically for gay individuals and because of this she does not understand this place as a city. When Jenny challenges her arguing that she is in fact from a 'city', Angela points to the existence of a cathedral as unimportant because, to her (and other women in this study), cities are more than those places which may hold the title of 'city'. In this sense, towns can be seen as 'urban' conglomerations but they are not given the status of 'city' and in everyday parlance, such as Angela and Jenny's discussion, are seen as distinct from cities and city life. The importance of the cities in terms of the possibilities of practicing of gay identities and the existence of visible territories (gay pubs) is not doubted in Angela and Jenny's account, rather the rigid definitions of cities and towns are contested.

The presence of gay and lesbian venues was key for a number of participants, and it was noted that the rural can be eroticised and used differently by men and women: KB: you said the country is quite closed. What
did you mean by that?

Michelle: well where I live there's no gays that I know of. No that's a lie actually there's more men that I know of. I used to work at a place called (name) and it was on a main road and, this is going to sound really, really crass, but there was toilets there. It was very well known for men. So I got to know quite a few that way but there's no scene around at all if I want to find one I have got to go to (name of city) or (name of another city) really... I mean there have got to be more lesbians and gays in Fieldtown than there are that go out to be fair. The same as in the country, there is bound to be at least like 1 in 10 if not more but no one is ever [out], because there is nowhere to go you can't do it.

(Michelle, white 20-25 individual interview, my emphasis, Fieldtown)

Knopp [82] contends that visible gay territories are politically important. Michelle reports that despite the presence of women who may be non-heterosexual the lack of a specific 'gay' venue, or even meeting points, such as toilets, renders them invisible 'because there is nowhere to go'. She differentiates between men and women. Men have the possibilities of anonymous sex in toilets, however women, in Michelle's view, do not $[6,43,75]$. The rural homosexual and the rural lesbian can have different opportunities, choices, practices,

\footnotetext{
5 These descriptors are provided to give more 'life' to participants, at the request of an anonymous referee. They are given for each participant once, when they first are directly quoted in the text.
}

identities and networks. Michelle's narrative points to friendships she has with gay men, such that these differences may not be barriers to interaction and solidarities, rather they indicate gendered life experiences.

Weston [1] contends that there has been a symbolic contrast between the urban and the rural in the 'gay imaginary'. In this research population size, liberal attitudes and 'freedom' were used by participants to make sense of their daily lives in towns. These could be dismissed as stereotypical and dubious assumptions of city life $[5,83,84]$. However, terms, ideas and theorisations that are subject to academic deconstructions, may still be important in conceptualising daily lives [52]. Conceptualisations of towns and cities can (in)form how the spatialisation of othering processes are perceived [85]:

\begin{abstract}
Leanne: I think Fieldtown is very, very middle class white and it's hard to sort of feel comfortable with your sexuality here. If I went back home to (Name of town north west of England) you wouldn't see me anywhere near [her girlfriend]. I would be walking four paces behind her at all times. You'd get your head kicked in so of course you have to adapt slightly. I am for pushing boundaries and stuff, [but] I think there is a time and I think you have got to be really careful how you do that. ... Obviously if I went in the middle of Manchester town centre I wouldn't give a shit.
\end{abstract}

(Leanne, white 20-25 individual interview, Fieldtown)

Leanne's narrative illustrates the diversity of towns here differentiating between Fieldtown and a town in the NorthWest of England. She intersects class and sexuality to argue that Fieldtown is a particularly homogenous representation of a rural English town. Leanne fears physical attack in the town in the North-West of England, but in the middle of Manchester she doesn't 'give a shit'. In this way, Leanne illustrates that the symbolic contrast between towns, as well as between towns and cities, can relate to perceptions of how nonheterosexual identities are/will be policed:
Nina: Blatantly nobody cares what you do in London you can stand naked in the middle of the tube station and nobody would notice. They would just walk past. Because if you look at somebody in London you are seen as an odd bod.

(Nina white 18-20, focus group, Fieldtown)

One policing process was that was frequently mentioned during this research was staring at non-heterosexual women, such that they/we feel unusual, 'deviant' and out of place [8589]. Nina contends that there are sights in London that would pass unnoticed (such as being naked) but which would be seen as deviant elsewhere. She argues that it is the observer who risks being othered in London, as it is unusual and out of place for people to stare in this 'anonymous' city. Similarly, Janet (individual interview) contended that there is a possibility of 'causing trouble' if people begin to stare and Leanne (individual interview) believed that there are more unusual aspects within cities that people would notice before they would pay attention to 'two people [who] are obviously you know just together'. Consequently, in contrast to the surveillance they experienced in their town, these women did not perceive themselves as subject to exclusionary and othering gazes, that 
were related to their sexualities, in large cities. London, in particular, featured in these narratives offering freedom, due to the perceived tolerance and nonchalance of the largest city in Great Britain that is densely populated and diverse. Population densities were also considered important for anonymity. 'Small' social networks were frequently mentioned as differentiating cities and towns, Hilary and Marie (focus group) understood small towns as being 'small-minded' and 'small hick, small town community'. Emma found Fieldtown stifling:

Emma: [In cities] everybody doesn't know your business. ... I mean our [her and her partner] lives have changed. If we had moved to a city ... our lives would change socially. ... We [would] do more things if we were in a city because if you are in a city then its different atmosphere, different attitudes.

(Emma white 30-35 and Jean white 30-35, coupled interview, Fieldtown)

At times, it has been assumed that gay and lesbian individuals can choose where they live related to their sexuality $[1,8,40]$, this may be related to assumptions of the 'pink pound' [90, 91]. However, many women (and potentially men) have only very limited choices about where they live [12]. Contrasting the possibilities of cities with the necessity of living in Fieldtown, Emma and Jean move between imaginings of cities and 'realities' of their lives in Fieldtown. When Emma was transferred by her employer to Fieldtown, from a Scottish city, she identified a major transformation in her life which she attributed to the small networks in Fieldtown where people 'know your business'. Fieldtown differs for Emma and Jean in relation to the atmospheres and attitudes towards sexualities that they have experienced in cities. Not only do these have implications for how Emma and Jean make sense of their everyday lives, they have specific manifestations. For example, Emma will not go to the gay club in Fieldtown in case she is seen by a work colleague or someone who is not aware that she is in a relationship with Jean. Both Emma and Jean contended that if they lived in a city they would enact their sexualities differently, leading to very different lives. This suggests that whilst non-heterosexual women do not need metropolitan centres, lesbian commercial social scenes or to visibly enact same-sex desire [16], this can be envied as an aspect of 'city living' unavailable to them in small towns.

The negotiation of lives in relation to employment and sexual expressions in the context of town living, is contrasted with the (im)possibilities of city lives and city living. It is this interplay between 'realities' and desires that can be omitted where the focus is on 'territories' and visible signifiers of identities. In moving between gay urban utopias and lesbian small town lives, sexual identities are constituted between the material and the symbolic [75]. In everyday lesbian lives in small towns, inhabited and imagined places are continually negotiated. Massey [53] argues the social relations that define a place are not solely within the place itself, here it can be seen that lives are also created through places 'beyond'.

\section{THE URBAN LESBIAN?: PROBLEMATISING CITY/ TOWN STEREOTYPES}

It has been contended that gay urban utopias may only exist for young, white, gay (or even straight) men [84, 92-94].
Moreover, it has been suggested to me in anecdotal conversation about this paper that the imaginings of cities presented here are somewhat 'distorted' and are therefore 'fantasies' in the sense that they are 'not real'/'make believe'. Imaginings of cities as pleasurable and idyllic were not universal. In contesting the universality of this form of mythologies, the problematic assumption that sexual minorities require urban landscapes for sexual expression is further contested [7], and conceptualisations of the lesbian urban acknowledged and diversified beyond the idyllic.

In examining the contradictions between imaginings and realities it is important to recognise the complexities of (re)negotiating relationships between the urban / rural.

\begin{abstract}
$\mathrm{KB}$ : do you think there is a difference between towns and cities and how you like if you lived in a city to you think you would have to?

Jenny: me personally, I don't think it would have much difference. I have lived in both so I didn't. I know I haven't changed much from one to another. I'm open and I like to be open so I haven't [changed] in coming to Fieldtown. I didn't sort of say 'oh my god, I have got to be more concerned about it'. Me and Vicky [ex-girlfriend] were never concerned about it so we just ran out and did what we wanted.
\end{abstract}

(Jenny, individual interview)

In contrast to others in this research Jenny did not see that she would be different in different places. She believes that she is 'open' and would not be more concerned about her sexuality in different places. She does not feel that moving to Fieldtown has restricted what she can and cannot do, unlike Emma and Jean above. Jenny, in this way, did not imaginatively differentiate towns and cities as some of the other women in the study did. However 'no difference' was not the only discourse used to diversely conceptualise small town lesbian lives. Whereas the women above saw cities as more open minded, Di has a different view:

Di: I would probably feel more comfortable in
like a smaller town. Not a small town but kind of
(town where she is from) size or Fieldtown size
town like being gay than I would if I was in a big
city. Because there [are] a lot of people you don't
kind of know the reactions you are going to get.
There is a lot more people. That's probably being
really stereotypical and prejudice. I mean in a
kind of city [you have] probably got a higher per-
centage of people who react badly or violently or
more aggressively towards you than in a place
like Fieldtown.

(Di individual interview, Fieldtown)

Di believes that in cities populated with a large number of people there is a higher probability of violent reactions to her sexuality. In contrast to the familiarity of towns, for Di, cities are unpredictable and potentially violent and homophobic. Di also illustrates that towns can be disparate phenomenon. She differentiates Fieldtown and the town she is from (population estimate 160,000), from 'small towns' recognising the diversity of the rural [48], yet implicitly reiterating the stereotype of 'more' rural areas as oppressive to alternative sexualities. The 
town/city dichotomy is not a replacement for the rural/urban dichotomy. As Di illustrates there are numerous complex perceptions that categorise ruralities, villages, towns and cities as 'repressive', liberating and the myriad of messy imaginings between.

Di's imaginings of towns as familiar (rather than in terms of small knowing networks) and cities (as potentially violent, rather than offering opportunities for unknown encounters) inform what she feels comfortable doing in these places:

\begin{abstract}
Di: ... if it's kind of a place you don't know, even in gay places if I don't know them, I still kind of act more reserved. Whereas like I will go somewhere like the (name of pub) which is like a straight pub but I am still a lot more open than if I went to like a gay pub, a gay pub I have never been to. It's all to with kind of where you feel comfortable rather than whether it's straight or gay
\end{abstract}

$\mathrm{KB}$ : and is that why you think maybe you feel more comfortable in a town?

Di: probably because you'd know the places know the people more. ... I know I go to the pub, like my local pub at home, every time I go there I know there is going to be the same people in there. Whereas if you went to the city, there would never be kind of the same people in there really. So I suppose it is all to do with feeling comfortable. ... The pub that I go to I worked there for a few years so I kind of do know them like to chat to. ... I don't think it is to do with just to do with being gay or straight or kind of where, it's how comfortable you feel.

\section{(Di, individual interview, Fieldtown)}

Other women in this study understood the small social networks of towns to be oppressive; however, Di draws on discourses and images of 'rural idylls' to see them as familiar and comfortable. She knows the people in the pub (bar) because of the small, familiar networks of her home town and this makes her feel safer and therefore able to be more 'open' about her sexuality and relationships with women. In contrast, the anonymity associated with the city is disconcerting, influencing how Di will act. She thus challenges the understanding of cities as sites where sexualities can be more openly practised and debunks the myth that a critical mass of identifiably gay areas will lead to feelings of safety, emphasising instead feelings of comfort in familiar 'straight' pubs. This in part resonates with Smith and Holt's [49] research which found that lesbians in a specific small town in the North of England, saw more rural areas as safe havens [47]. Here, Di's perceptions of the size of each town and small social networks enable her to have a familiarity that is tied into her personal biography (in this case returning to a pub where she worked and is, therefore, known). Thus, it is not simply the town that enable these feelings of comfort, rather the interconnections between Di and her 'local' pub contrast (unfavourably) with anonymous, and potentially violent encounters in large cities (unlike Michelle, above, who sees these as limiting opportunities to meet people).
These interconnections and uses of towns vary through time, such that feelings of 'comfort' can develop even where hostility is felt. This can lead to a reading of micro-spaces within towns and, therefore, Janet differentiates how she acts in different spaces in Fieldtown:

Janet: I am walking around town now holding
Margrit's hand and stuff and I am just thinking I
don't care. I have kind of got to the stage now
where I am tired of having to hide everything. I
am tired of, you know, not showing that I have
something with her. But it's like we walked
around town on Saturday [and] I was holding her
hand and stuff like maybe not right in the centre
of town. But when we were in the shops and cer-
tain like walking back here [to Janet's house] and
stuff. I just think I just can't be bothered with it
any more.

(Janet white 18-20 and Lorraine white 18-20, focus group, Fieldtown)

Janet altered how she acted with her partners when she moved from London to Fieldtown. She believed she could not do certain things in Fieldtown, such as holding her girlfriend's hand, which she was able to do in London. The policing of her behaviours in the town have clearly frustrated her. Where she shows affection altered through time as she became more familiar with the micro-geographies of the town. Janet's description of her practices is somewhat different to Di's feeling of comfort. Janet now transgresses codes she identifies in Fieldtown and holds her girlfriend's hand. However, as in Valentine's [95] discussion of lesbians' time-space negotiations, she carefully delimits spaces where she can and cannot do this complicating the dichotomous views of towns and cities presented earlier. The main street of Fieldtown was often described as very heterosexual, being comprised mainly of 'families and push chairs'. Perhaps this is the reason that Janet points to this space as one where she would not hold her girlfriend's hand (this has resonances with Valentine's [68] discussion of lesbians uses of the street). Also notably, Janet chooses times when college 'lads' (who she was concerned about bumping into) would not be around (on a Saturday the majority of 'college lads' Janet refers to would be playing or watching sport), and specific shops where she would hold her girlfriends hand. Therefore, in line with previous literature, towns (as well as cities) can be conceptualised as fragmented with different spaces taking on particular meanings at specific times [95]. What this reading also contends is that lesbian identities are not solely practised within 'gay areas' [54] and lesbian/non-heterosexual women's geographies can be informed by 'frustration', desire, rage and other emotions that have yet to be fully accounted for in the literature.

Rather than offer explanations for imaginings or practices on the basis of categories (such as age, time being out and so forth), this paper illustrates some of the complex rural/urban idylls and practices that create lesbian lives in small towns. The accounts in this section diversify narratives of cities and towns and contest the hierarchisation of urban utopias and repressive ruralities. They point to the messy spaces between and beyond urban/rural dichotomies, but they also point to the place of emotions, fear, anger, frustration and desire in living in a small town, which contrasts with a gay urban utopia. Such lesbian geographies are never simply located or locatable and 
they point to the need to examine diverse intersections between spaces, practices, identities and particularly imaginings.

\section{CONCLUSION}

This paper seeks to reiterate the importance of lesbian geographies in geographies of sexualities, and the place of these alongside queer geographies [17]. In this context, it has augmented geographies of sexualities by using lesbians/nonheterosexual women's 'imaginings' to de-territorialise sexualised spaces away from urban utopias and into small towns. Using Bell's [75] discussion of the homosexual rural and the rural homosexual, the paper explored the intertwined constitution of the idyllic urban lesbian and lesbian small town lives. The research found that lives are lived by referring to urban utopias 'beyond' small town lives [53] and such imaginings have productive effects. With technologies, tourisms and other messy interstices, movements and interactions, the easy location of lives within either the urban/rural needs to be revisited. This 'movement' may not be embodied through migration it could be virtual and/or 'imagined'. The intersections of the imaginative and 'real' could offer further investigative avenues illustrating that 'utopias' and 'oppressions' are not simply place-based but (re)constructed, and understood, in relation to places 'beyond'.

\section{ACKNOWLEDGEMENTS}

I would like to thank all the women who participated in this research for their time, effort and support. Thanks go to Andrew Church and Cara Aitchison whose help, guidance and advice is gratefully appreciated. I would also like to thank Becky Elmhirst and Darren Smith for their comments and advice about this paper.

\section{REFERENCES}

[1] Weston K. Get thee to a big city: Sexual imaginary and the greta gay migration. GLQ: J Lesbian Gay Stud 1995; 2(253): 277.

[2] Gorman-Murray A. Rethinking queer migration through the body. Soc Cult Geogr 2007; 8(1): 105-21.

[3] Knopp L, Brown M. Queer diffusions. Environ Plan D Soci Space 2003; 21: 409-24.

[4] Knopp L. Ontologies of place, placelessness, and movement: Queer quests for identity and their impacts on contemporary geographic thought. Gender Place Culture 2004; 11(1): 121-34.

[5] Myslik W. Renegotiating the social/ sexual identities of places: Gay communities as safe havens or sites of resistance? In: Duncan N, Ed. Body Space: Destabilising geographies of gender and sexuality. London: Routledge 1996; pp. 156-69.

[6] Kramer JL. Bachelor farmers and spinsters: Gay and lesbian identities and communities in rural North Dakota. In: Bell D, Valentine G, Eds. Mapping desire: Geographies of Sexualities 1995; pp. 200-13.

[7] Phillips R, Watt D, Shuttleton D. De-centring sexualities: Politics and representations beyond the metropolis. London: Routledge 2000

[8] Valentine G. Making space: Separatism and difference. In: Jones III JP, Nast HJ, Roberts SM, Eds. Thresholds in feminist geography: Difference, methodology, representation. Oxford: Rowman and Littlefield 1997; pp. 65-75.

[9] Bell D. Fragments for a queer city. In: Bell D, Binnie J, Holliday R, Longhurst R, Peace R, Eds. Pleasure zones: Bodies, cities, spaces. Syracuse University Press: New York 2001; pp. 84-102.

[10] Jarvis H, Pratt AC, Cheng-Chong Wu P. The secret life of cities. London: Prentice Hall 2003.

[11] Butler J. Bodies that Matter. London: Routledge 1993

[12] Taylor Y. Working class lesbian life: Classed outsiders. Basingstoke: Palgrave 2007.

[13] Ahmed S. The cultural politics of emotion. Edinburgh: Edinburgh University Press 2004.
[14] Binnie J. Sexuality, the erotic and geography: Epistemology, methodology and pedagogy. In: Browne K, Lim J, Brown G, Eds. Geographies of sexualities: Theory, practices and politics. London: Ashgate 2007; pp. 29-38.

[15] Browne K. Lesbian geographies. Soc Cult Geogr 2007; 8(1): 1-7.

[16] Peace R. Producing lesbians: Canonical proprieties. In: Bell D, Binnie J, Holliday R, Longhurst R, Peace R, Eds. Pleasure zones: Bodies, cities, spaces. New York: Syracuse University Press 2001; pp. 29-54.

[17] Browne K. Challenging 'queer' geographies. Antipode 2006; 38(5): 885-93.

[18] Oswin N. Critical geographies and the uses of sexuality: Deconstructing queer space. Prog Hum Geogr 2007.

[19] Calhoun C. In: Vicinus M, Ed. The gender closet: Lesbian disappearance under the sign "Women". Lesbian Subjects: A Feminist Reader. Fem Stud Indiana University Press, Blomington 1995; 21(1): 7-34.

[20] Alcoff L. The Politics of postmodern feminism, revisited. Cult Stud 1997; 11(1): 5-27.

[21] Walters SD. From here to queer: Radical feminism, postmodernism and the lesbian menace (or why can't a woman be more like a fag?). Signs 1996; 21(4): 830-69.

[22] Andrucki M, Elder G. Locating the state in queer space. Soc Cult Geogr 2007; 8(1): 89-104.

[23] Halberstam J. In a queer time and place: Transgender bodies, subcultural lives. New York: New York University Press 2005.

[24] Oswin N. Towards radical geographies of complicit queer futures. ACME: Int E-J Crit Geogr 2005; 3(2): 79-86.

[25] Sothern M. (Un)queer patriarchies: Or, 'what we think when we fuck'. Antipode 2004; 36(1): 183-91.

[26] Warner M. The trouble with normal: Sex, politics, and the ethics of queer life. New York: The Free Press 1999.

[27] Van Hoven B, Horschelmann K. Spaces of masculinities. London: Routledge 2007.

[28] Browne K. Snowball sampling: Using social networks to research non-heterosexual women. Int J Soc Res Methodol 2005; 8(1): 47-60.

[29] Browne K. Negotiations and fieldworkings: Friendship and feminist research. ACME: Int E-J Crit Geogr 2003; 2(2): 132-46.

[30] Browne K, Lim J, Brown G. Geographies of sexualities: Theories, practices and politics. London: Ashgate 2007.

[31] Bell D, Valentine G. Mapping desires: Geographies of sexualities. London: Routledge 1995.

[32] Binnie J, Valentine G. Geographies of sexuality-a review of progress. Prog Hum Geogr 1999; 23(2): 175-87.

[33] Valentine G. Introduction: From nowhere to everywhere. J Lesbian Stud 2000; 4(1): 1-9.

[34] Collins A. Sexuality and sexual services in the urban economy and socialscape: An overview. Urban Stud 2004; 41(9): 1631-41.

[35] Collins A. Sexual dissidence, enterprise and assimilation: Bedfellows in urban regeneration. Urban Stud 2004; 41(9): 1789-806.

[36] Hughes H. Marketing gay tourism in Manchester: New market for urban tourism or destruction of 'gay space'? J Vacation Mark 2002; 9(2): 152-63.

[37] Sibalis M. Urban space and homosexuality: The example of the Marais, Paris' 'gay ghetto'. Urban Stud 2004; 41(9): 1739-58.

[38] Skeggs B, Moran L, Tyrer P, Binnie J. Queer as folk: Producing the real of urban space. Urban Stud 2004; 41(9): 1839-56.

[39] Kitchin R. Sexing the city: The sexual production of space in Belfast, Manchester and San Francisco City 2002; Vol. 6(2): pp. 205-18.

[40] Kitchin R, Lysaght K. Heterosexism and the geographies of everyday life in Belfast, Northern Ireland. Environ Plan A 2003; 35: 489-510.

[41] Kitchin R, Lysaght K. Sexual citizenship in Belfast, Northern Ireland. Gender Place Cult 2004; 11(1): 83-103.

[42] Knopp L. Ontologies of place, placelessness, and movement: Queer quests for identity and their impacts on contemporary geographic thought. Gender Place Cult 2004; 11(1): 121-34.

[43] Bell D. Eroticising the rural. In: Phillips R, West D, Shuttleton D, Eds. Decenting sexualities: Politics and representations beyond the metropolis. London: Routlege 2000; pp. 83-101.

[44] Lambevski S. Suck my nation: Masculinity, ethnicity and (homo)sex. Sexualities 1999; 4(2): 397-419.

[45] Binnie J, Skeggs B. Cosmopolitian knowledge and the production and consumption of sexualised space: Manchester's gay village. The Sociol Rev 2004; 52(1): 39-61.

[46] Nast H. Queer patriarchies, queer racisms, international. Antipode 2002; 34(5): 874-909.

[47] Bell D, Valentine G. Queer country: Rural lesbian and gay lives. J Rural Stud 1995; 11(2): 113-22. 
[48] Spurlin W. Remapping same-sex desire: Queer writing and culture in the American heartland. In: Phillips R, Watt D, Shuttleton D, Eds. Decentering sexualities: Politics and representations beyond the metropolis. London: Routledge 2000. pp. 182-98.

[49] Smith D, Holt L. 'Lesbian migrants in the gentrified valley and 'other' geographies of rural gentrification. J Rural Stud 2005; 21:313-22.

[50] Amin A, Thrift N. Cities: Reimagining the Urban. Cambridge: Polity 2002.

[51] Glass R. Urban images. In: Harrison GA, Gibson JB, Eds. Man in urban environments. Oxford: Oxford University Press 1969; pp. 34967.

[52] Halfacree KH. Talking about rurality: Social representations of the rural as expressed by residents of six English Parishes. J Rural Stud 1995; 11(1): 1-20.

[53] Massey D. Space, place and gender. Cambridge: Polity Press 1994.

[54] Podmore JA. Lesbians in the crowd: Gender, sexuality and visibility along Montreal's Boul St-Laurent. Gender Place Cult 2001; 8(4): 333-55.

[55] Nash CJ, Bain AL. "Reclaiming raunch?": Spatializing queer identities at a Toronto women's bathhouse event. Soc Cult Geogr 2007; 8(1): 47-62.

[56] Quilley S. Manchester's 'village in the city': The gay vernacular in a post-industrial landscape of power. Transgressions 1995; 1(1): 36-50.

[57] Aldrich R. Homosexuality and the city: An historical overview. Urban Stud 2004; 41(9): 1719-37.

[58] Castells M. The city and the grassroots: A cross-cultural theory of urban social movements. London: Edward Arnold 1983.

[59] Knopp L. Some theoretical implications of gay involvement in an urban land market. Polit Geogr Q 1990; 9(4): 337-52.

[60] Lauria M, Knopp L. Towards an analysis of the role of gay communities in the urban renaissance. Urban Geogr 1985; 6: 152-69.

[61] Nash CJ. Contesting Identity: Politics of gays and lesbians in Toronto in the 1970s. Gender Place Cult 2005; 12(1): 113-35.

[62] Cooper D. 'Well, you go there to get off': Visiting feminist care ethics through a women's bathhouse. Fem Theory 2007; 8(3): 243-62

[63] Cieri M. Between being and looking: Queer tourism promotion and lesbian social space in greater philadelphia. ACME: Int E-J Crit Geogr 2003; 2(2): 147-66.

[64] Valentine G. Desperately seeking Susan: A geography of lesbian friendships. Area 1993; 25(2): 109-16.

[65] Valentine G. (Hetero) sexing space: Lesbian perceptions and experiences in everyday spaces. Environ Plan D 1993; 11: 395-413.

[66] Munt SR. The lesbian flaneur. In: Bell D, Valentine G, Eds. Mapping desire: Geographies of Sexualities. London: Routledge 1995; pp. $114-25$.

[67] Rothenburg T. 'And she told two friends': Lesbians creating urban social space. In: Bell D, Valentine G, Eds. Mapping desire: Geographies of sexualities 1995; pp. 165-81.

[68] Valentine G. (Re)negotiating the "Heterosexual Street": Lesbian productions of space. In: Duncan N, Ed. Body space: Destabilising geographies of gender and sexualities. London: Routledge 1996; pp. 146-55.

[69] Gorman-Murray A, Waitt G, Gibson C. Chilling out in the country: Interrogating Daylesford as the 'gay/lesbian' rural idyll 2007; pp. 1-7.

[70] Phillips R. Imagined geographies and sexuality politics: The city, the country and the age of consent. In: Phillips R, West D, Shuttleton D, Eds. Decentering sexualities: Politics and representations beyond the metropolis. London: Routledge 2000; pp. 102-24.

[71] Little J. Otherness, representation and the cultural construction of rurality. Prog Hum Geogr 1999; 23(3): 437-42.
[72] Murdoch J, Pratt A. Rural studies: Modernism, ppostmodernism and the post rural. J Rural Stud 1993; 9(4): 411-27.

[73] Phillips M. The restructuring of social imaginations in rural geography. J Rural Stud 1998; 14(2): 121-53.

[74] Philo C. Postmodern rural geography? A reply to Murdoch and Pratt. J Rural Stud 1993; 9(4): 429-36.

[75] Bell D. Homosexuals in the heartland: Male same-sex desire in the rural United States. In: Cloke P, Ed. Country Visions. Harlow, Essex: Pearson 2003; pp. 178-94.

[76] Chisholm D. Queer constellations: Subcultural space in the wake of the city. Minneapolis: University of Minnesota Press 2004.

[77] Hubbard P. Revenge and injustice in the Neoliberal city: Uncovering Masculinist Agendas. Antipode 2004; 36(4): 665-86.

[78] Lees L. The emancipatory city: Paradoxes and possibilities. London: Sage 2004.

[79] Pile S. What is a city? In: Massey D, Allen J, Pile S, Eds. City worlds. London: Routledge 1999; pp. 3-52.

[80] Brown M, Knopp L. Queer cultural geographies- We're here! We're queer! We're over there, too! In: Anderson K, Domosh M, Pile S, Thrift N, Eds. Handbook of Cult Geogr. London: Sage 2003; pp. 31324.

[81] Cieri M. Between being and looking: Queer tourism promotion and lesbian social space in Philadelphia. ACME: Int E-J Crit Geogr 2003; 2: 147-66.

[82] Knopp L. Sexuality and urban space: gay male identity politics in the United States, the United Kingdom, and Australia. In: Fincher R, Jacobs J, Eds. Cities of Difference. London: Guilford 1998. pp. 14976.

[83] Kirby S, Hay I. (Hetero) sexing space: Gay men and "straight" space in Adelaide Australia. Prof Geogr 1997; 49(3): 295-305.

[84] Whittle S. The margins of the city: Gay men's urban lives. Manchester: Arena 1994.

[85] Browne K. (Re)making the other: Heterosexualising everyday space. Environ Plan A 2006; 39(4): 996-1014.

[86] Browne K. Genderism and the bathroom problem: (Re)materialising sexed sites, (re)creating sexed bodies. Gender Place Cult 2004; 11(3): 331-46.

[87] Browne K. Stages and streets: Reading and misreading female masculinities. In: Van Hoven B, Horschelmann K, Eds. Spaces of Masculinities. London: Routledge 2005; pp. 237-48.

[88] Cresswell T. Weeds, plagues and bodily secretions: A geographical interpretation of metaphors of displacement. Ann Assoc Am Geogr 1997; 87(2): 330-45.

[89] Cresswell T. In place/out of place: Geography, ideology and transgression. London: University of Minnesota Press 1996.

[90] Badgett MVL. Money, myth and change: The economic lives of lesbians and gay men. Chicago: University of Chicago Press 2003.

[91] Binnie J. The globalisation of sexuality. London: Sage 2004.

[92] Casey M. The queer unwanted and their undesirable 'otherness'. In: Browne K, Lim J, Brown G, Eds. Geographies of sexualities. London: Ashgate 2007; pp. 125-35.

[93] Doan PL. Queers in the American city: Transgendered perceptions of urban space. Gender Place Cult 2007; 14(1): 57-74.

[94] Casey M. De-dyking queer space(s): Heterosexual female visibility in gay and lesbian spaces. Sexualities 2004; 7(4): 446-61.

[95] Valentine G. Negotiating and managing multiple sexual identities: Lesbian time management strategies. Trans Inst Br Geogr 1993; 18: $237-48$. 